\title{
Influence of heat treatment on the sensory and physical characteristics and carbohydrate fractions of french-fried potatoes (Solanum tuberosum L.)
}

\author{
Natalia Carvalho Montenegro de VASCONCELOS ${ }^{1 *}$, Silvana Magalhães SALGADO ${ }^{1}$, Alda Verônica Souza LIVERA ${ }^{1}$, \\ Samara Alvachian Cardoso de ANDRADE², Michelle Galindo de OLIVEIRA ${ }^{3}$, Tânia Lucia Montenegro STAMFORD ${ }^{1}$
}

\begin{abstract}
The aim of this study was to analyze the impact that heat treatment with salts and freezing processes on the sensory, instrumental, and physico-chemical characteristics of fried potatoes of the Monalisa cultivar. The potatoes were blanched in distilled water (P); sodium chloride solution (B1); calcium chloride solution (B2), and a solution with both of these salts (B3). They were then pre-cooked and frozen for 24 hours and for 30 days. After frying, sensory characteristics were analyzed (color, texture, flavor, oiliness), along with overall preference and instrumental determinations of texture, color, and oil content. Further tests were conducted on the sample with the best results in the sensory analysis (B1), along with sample $\mathrm{P}$ as a control, to determine granule microstructure, carbohydrate fractions, glycemic index, and glycemic load. Blanching B3, despite reducing oil absorption and providing less oiliness, obtained lesser overall preference. Freezing for 30 days increased the lightness, except for when sodium chloride was used, which intensified the color yellow. The use of sodium chloride did not interfere with the type of starch granules, nor with the formation of resistant starch; however, longer freezing time reduced the glycemic index and concentrated the dietary fiber content. All samples exhibited low glycemic index and moderate glycemic loads.
\end{abstract}

Keywords: blanching; sodium chloride; calcium chloride; texture; glycemic index; freezing.

Practical Application: Improve the sensory quality and the use of starch of French fries.

\section{Introduction}

Carbohydrates are the most important energy source in the human diet, and can be found in abundance in tubers such as potatoes (Solanum tuberosum 1.), a starch source that is widely consumed around the world (Pereira et al., 2005). Their granules comprise amylose and amylopectin molecules, which are internally organized to ensure the exhibition of properties such as type B semi-crystallinity and granting greater resistance to enzymatic digestion (Lee et al., 2011).

Among the methods of preparing this tuber, french-fried potatoes are highly appreciated by the population due to the pleasant sensory characteristics that they acquire during dry heat processing. This food has a high glycemic index (GI), which can reach 107 and is related to the high percentage (65-85\% of dry weight) and bioavailability of starch, which can vary according to the cultivar and the processes used (Foster-Powell et al., 2002; Food and Agriculture Organization, 1998; Goñi et al., 2002; Sidney University Glycemic Index Research Service, 2011). Furthermore, there are benefits tied to the consumption of this food, and evidence that when it is properly prepared, it is a vehicle for essential fatty acids and reduces the formation of trans fatty acids, and absorbs little fat from frying (Sanibal \& Mancini, 2004).
Existing processes in the food industry, such as blanching, are being improved, which in addition to its previously known functions has demonstrated the ability to modify the rheological properties of starch. Operations such as blanching and freezing are able to modify the internal structural arrangement of amylose and amylopectin by cooking in water, which promotes gelatinization, and the subsequent downgrading during cooling and freezing. This helps in extending the benefits of ingesting this type of carbohydrate and reducing its negative impact on the consumer's diet and health.

The use of salts during blanching is a process that modifies the sensory characteristics (Bunger et al., 2003), improving color, increasing external crispness and internal softness, adding flavor, and reducing oil content, along with possible changes in the structure of the starch granule due to the interaction of salts such as sodium and calcium chloride with the internal components and allowing them to be better utilized. Freezing, besides being used to increase the shelf life of foods, can alter the bioavailability of carbohydrates, as scientific reports show that this favors the formation of the indigestible starch fraction, resistant starch (RS), which is associated with benefits to intestinal flora and likely related to the reduction in glycemic response (Bunger et al., 2003; Rimac-Brnčić et al., 2004; Pedreschi et al., 2007). 
Considering the high intake of this food and the FAO/WHO (Food and Agriculture Organization, 1998) recommendation favoring foods with a low-to-moderate glycemic index for health benefits, blanching with added salts along with freezing presents a technological alternative for modifying the bioavailability of the starch, thereby helping to build knowledge and give french-fried potatoes a place in this food trend. Considering this scenario, we studied the conditions for processing pre-fried frozen potatoes in order to determine their influence on physical parameters, sensory attributes, and the carbohydrate fractions of this food.

\section{Methods}

\subsection{Acquisition of raw materials and preparation of samples}

Potatoes (Solanum tuberosum 1., Monalisa cultivar) were acquired in the Pernambuco State Supply Center (CEASA) in the city of Recife. They were cleaned in running water and sanitized in a $100 \mathrm{ppm}$ chlorine solution for $15 \mathrm{~min}$. Next, they were peeled, cut into $10 \mathrm{~mm} \times 10 \mathrm{~mm} \times 90 \mathrm{~mm}$ strips, and washed in running water to remove excess surface starch. They were then blanched in salt solutions at $85{ }^{\circ} \mathrm{C}$ for $5 \mathrm{~min}$, as outlined by Bunger et al. (2003) and Rimac-Brnčić et al. (2004), and adapted for this study as follows: standard (P), using distilled water; $\mathrm{B} 1,3 \% \mathrm{NaCl}$ solution; $\mathrm{B} 2,3 \% \mathrm{CaCl}_{2}$ solution; $\mathrm{B} 3,3 \% \mathrm{CaCl}_{2}+3 \% \mathrm{NaCl}$ solution.

After blanching, the samples were cooled in a $5^{\circ} \mathrm{C}$ ice bath for $2 \mathrm{~min}$, drained, and dried with paper towels. The blanched potato strips were pre-cooked in ratio oil/potato used $(6: 1)$ at $180{ }^{\circ} \mathrm{C}$ for $1.5 \mathrm{~min}$ in an aluminum pot, in proportions of $100 \mathrm{~g}$ sample. Oil temperature was monitored using an infrared thermometer (Vendruscolo \& Zorzella, 2002).

Excess surface oil was removed with 4 sheets of paper towel, and the blanched and pre-cooked potato strips were stored in lidded plastic containers and frozen in the freezer at $-18^{\circ} \mathrm{C}$ for 24 hours and 30 days. After the freezing periods, they were deep fried by immersing in soybean oil at $180^{\circ} \mathrm{C}$ for $4 \mathrm{~min}$ in the same proportions and placed on paper towels to drain.

\subsection{Microbiological analysis}

After freezing, evaluations were performed to establish the feasibility of analysis, according to Brazilian National Health Surveillance Agency Resolution no. 12 (Brasil, 2001), which established parameters as follows: coliforms at $45^{\circ} \mathrm{C} / \mathrm{g}$ (AOAC 966.24), coagulase-positive staphylococcus/g (AOAC 975.55), and Salmonella sp/25 g (AOAC 967.26) (Association of Official Analytical Chemists, 2002).

\subsection{Sensory analysis}

Thirty volunteers were recruited, including staff and students at UFPE. Of these, depending on availability, 23 tasters were selected, untrained, invited to voluntarily participate and authorizing participation in the study and dissemination of the data by signing the informed consent form (Process: 940.907, CAAE: 11324412.0.0000.5208).
The samples were coded with three-digit and served on a plastic tray with a glass of water. The standard sample was always the first in the order of presentation, then the treatments at varying order. The samples were evaluated immediately after frying in individual booths at room temperature, at the Dietary Technique Laboratory of UFPE.

Was executed multiple comparison test NBR 13526 (Associação Brasileira de Normas Técnicas, 1995) in order to evaluate the differences in the experimental samples (B1, $\mathrm{NaCl}$ solution $3 \%$; $\mathrm{B} 2 \mathrm{CaCl} 2$ solution $3 \%$; $\mathrm{B} 3 \mathrm{CaCl} 2$ solution $3 \%+3 \% \mathrm{NaCl}$ ) with respect to standard sample ( $\mathrm{P}$, in distilled water) for color, flavor, texture and oiliness. After the multiple comparison test was applied to one affective tasters preferred category test, in order to position in descending order experimental samples according to the overall preference (Internacional Standard Organization, 2006).

\subsection{Instrumental color analysis}

We used the CIELAB $\left(\mathrm{L}^{*}, \mathrm{a}^{*}\right.$, and $\left.\mathrm{b}^{*}\right)$ scale with a colorimeter (CR-400, Konica Minolta Sensing, Japan) using a D65 illuminant, measuring the ends and the center of the fried potato strips (International Comission on Ilumination, 2004).

\subsection{Instrumental texture analysis}

Texture was analyzed using a CT3 texturometer (Brookfield, Middleboro, MA, United States of America) with a $25 \mathrm{~kg}$ load cell. The fried potato strips were placed on a rectangular base (TA-BT-KIT), where the penetration test was performed using a TA39 cylindrical tip test probe $(2 \mathrm{~mm} \times 20 \mathrm{~mm})$. The strips were perforated to a depth of $4.0 \mathrm{~mm}$ at a crosshead speed of $1.5 \mathrm{~mm} / \mathrm{s}$ at five points on the same side of the potato strip according to the methodology of Pardo et al. (2000). The measurements were performed immediately in triplicates after frying, and the load was expressed in grams-force (gf).

\subsection{Oil}

Oil content were determined by hot extraction via the Soxhlet method (AOAC 963.15), using diethyl ether as a solvent (Association of Official Analytical Chemists, 2002).

\subsection{Selection of treatment}

After the sensory analysis was completed, the treatment with the most satisfactory results for the multiple comparison test attributes, along with the highest overall preference, was selected for further analysis (Scanning electron microscopy, $\mathrm{X}$-ray diffraction, Carbohydrate fractions, glycemic index, and glycemic load). The standard sample that was blanched in distilled water $(\mathrm{P})$ was also analyzed as a control to verify the effect of the salts used.

\subsection{Scanning electron microscopy (SEM)}

The isolated starch from the fried potatoes (Rocha et al., 2008) was mounted on the stubs with double sticky carbon tape and coated with a thin film of gold under vacuum. We used a FEI 
Quanta 200 F (United States of America) field emission gun scanning electron microscope at an accelerating potential of $20 \mathrm{kV}$ in high vacuum mode, and recorded images with magnifications of up to $1200 \times$.

\subsection{X-ray diffraction}

The isolated starch was analyzed in a D8-Advance diffractometer (Bruker, Germany) operating at $40 \mathrm{kV}$ and $40 \mathrm{~mA}$ and producing $\mathrm{Cu}$ Ka radiation, scanning through the $2 \theta$ range of $4-30^{\circ}$ and at a $1 \mathrm{~s}$ step time. The diffraction patterns obtained were compared to the Joint Committee on Powder Diffraction Standards (JCPDS) stanldard for potato starch, from the International Centre for Diffraction Data (ICDD). We also determined the percentage of crystallinity and amorphous fraction of the samples and analyzed them using DIFFRAC.EVA V3.0 software (Bruker, Germany).

\subsection{Carbohydrate fractions, glycemic index, and glycemic load}

Resistant starch (RS) was quantified using the enzymatic gravimetric method (AOAC 2002.02). The level of dietary fiber (DF) was also determined using the enzymatic gravimetric method (AOAC 991.43) (Association of Official Analytical Chemists, 2002).

The in vitro glycemic index (GI) of the samples was determined using Goñi’s method (Goñi et al., 2010) with the glucose oxidase peroxidase (GOPOD) kit. The glycemic load (GL) was also determined (Salmerón et al., 1997).

\subsection{Statistical analysis}

For multiple comparison and preference ranking sensory tests, we used statistical methods by Dunnett and Newell \& MacFarlane, respectively. Data was processed using variance analysis, along with Duncan's means comparison test, all at a 5\% significance level, using Statistica 6.0 for Windows (Statasoft, Pacific Pty Ltd, Victoria, Australia).

\section{Results and discussion}

Microbiological analysis of the samples allowed carry safely sensory tests of implementing sensory analysis, because they met the quality standard established in Brazilian Resolution no. 12 standard (Brasil, 2001), demonstrating that the pasteurization caused by blanching in hot water was efficient (Oner \& Walker, 2011).

Studies show that the texture of french fries is the most important attribute for preference, and that this is directly related to specific gravity, total solid content, starch content, cell size, surface area, and pectin content (Troncoso et al., 2009). Of the blanching results, B1 frozen for 30 days obtained the best sensory result with respect to the texture attribute (Table 1). Samples B2 and B3 for both freezing periods yielded a texture that was inferior to the control and less-preferred (Table 1).

Overall preference showed that regardless of freezing time, blanching with B1 was generally the most preferred by the tasters with the lowest score (61). In particular, treatment with B1
Table 1. Sensory evaluation of french-fried potatoes subjected to thermal treatments.

\begin{tabular}{|c|c|c|c|c|c|}
\hline \multicolumn{6}{|c|}{ Sensory Analysis } \\
\hline \multicolumn{6}{|c|}{ Multiple comparison test } \\
\hline Attributes & Freezing & $\mathrm{P}$ & B1 & B2 & B3 \\
\hline \multirow[t]{2}{*}{ Texture } & $24 \mathrm{~h}$ & $5 \mathrm{a}$ & $5.61 \mathrm{a}$ & $2.74 \mathrm{~b}$ & $3.91 \mathrm{~b}$ \\
\hline & $30 \mathrm{~d}$ & $5 \mathrm{a}$ & $6.26 \mathrm{~b}$ & $3.65 b$ & $3.96 b$ \\
\hline \multirow[t]{2}{*}{ Color } & $24 \mathrm{~h}$ & $5 \mathrm{a}$ & $5.87 \mathrm{~b}$ & $3.91 \mathrm{~b}$ & $4.13 \mathrm{~b}$ \\
\hline & $30 \mathrm{~d}$ & $5 \mathrm{a}$ & $5.96 \mathrm{~b}$ & $3.91 \mathrm{~b}$ & $4.74 \mathrm{a}$ \\
\hline \multirow[t]{2}{*}{ Flavor } & $24 \mathrm{~h}$ & $5 \mathrm{a}$ & $6.13 b$ & $2.91 \mathrm{~b}$ & $3.74 b$ \\
\hline & $30 \mathrm{~d}$ & $5 \mathrm{a}$ & $6.0 \mathrm{~b}$ & $4.09 \mathrm{~b}$ & $4.22 \mathrm{~b}$ \\
\hline \multirow[t]{2}{*}{ Oiliness } & $24 \mathrm{~h}$ & $5 \mathrm{a}$ & $4.87 \mathrm{a}$ & $5.3 \mathrm{a}$ & $5.87 \mathrm{~b}$ \\
\hline & $30 \mathrm{~d}$ & $5 \mathrm{a}$ & $5.78 \mathrm{~b}$ & $5.09 \mathrm{a}$ & $5.48 \mathrm{a}$ \\
\hline \multicolumn{6}{|c|}{ Preference ranking test } \\
\hline Freezing & \multicolumn{2}{|c|}{ B1 } & \multicolumn{2}{|c|}{ B2 } & B3 \\
\hline $24 \mathrm{~h}$ & \multicolumn{2}{|c|}{$34 \mathrm{~b}$} & \multicolumn{2}{|c|}{$58 \mathrm{a}$} & $46 \mathrm{ab}$ \\
\hline $30 \mathrm{~d}$ & \multicolumn{2}{|c|}{$27 \mathrm{~b}$} & \multicolumn{2}{|c|}{$59 \mathrm{a}$} & $51 \mathrm{a}$ \\
\hline \multicolumn{6}{|c|}{$\begin{array}{l}\text { Blanching: } \mathrm{P} \text { (distilled water); } \mathrm{B} 1(\mathrm{NaCl} 3 \%) ; \mathrm{B} 2\left(\mathrm{CaCl}_{3} 3 \%\right) \text {; and } \mathrm{B} 3\left(\mathrm{NaCl} 3 \%+\mathrm{CaCl}_{2} 3 \%\right) \text {. } \\
\text { Freezing times: } 24 \mathrm{~h} \text { ( } 24 \text { hours) and } 30 \mathrm{~d}(30 \text { days). In the multiple comparison test, } \\
\text { multiple non-control letters differed significantly (statistically) for each treatment from } \\
\text { the } 5 \% \text { significance level in Dunnett's test, and in the ranking by preference test at the } \\
5 \% \text { significance level for the Newell and } \mathrm{Mc} \text { Farlane test. }\end{array}$} \\
\hline
\end{tabular}

frozen for 30 days was the most preferred method and the one that most significantly differed from other treatments (Table 1).

As for instrumental texture, it was observed that the highest average force applied in the penetration test (220 gf) was for treatment with B3 frozen for $24 \mathrm{~h}$ (Figure 1). However, the sensory data consider this treatment "below standard," indicating that the greater the force needed to pierce the surface of the potato, the greater the rigidity of the tissue and the less crispy the fried potatoes. This result is justified, because during the blanching, pectin methyl esterase is activated and hydrolyzes the pectin methyl ester linkages, which in turn reacts with the calcium in the solution, increasing the firmness of the tissue (Zvitov-Ya'ari \& Nussinovitch, 2014).

Regarding instrumental texture, the lowest average force applied (81 gf) was observed in the french fries subjected to blanching treatment with B1 frozen for $24 \mathrm{~h}$ (Figure $1 \mathrm{~B}$ ). This result corroborates with Figure 1B, which shows that the texture of this sample was deemed as "Slightly better than the standard."

The sensory evaluation of the color attribute highlights treatment with B1 as "Slightly better than the standard" regardless of the freezing time (Table 1). The color is affected by the type of blanching treatment used; Pedreschi et al. (2009) observed that a $3 \% \mathrm{NaCl}$ solution reduces non-enzymatic browning by leaching the reducing sugars and reducing the acrylamide content. According to the observations from the sensory analysis participants, the color of the french fries varied as follows: $\mathrm{NaCl}$ produced a more golden color, while the control samples were more brownish, and $\mathrm{CaCl}_{2}$ produced a paler but uniform coloration.

Table 2 shows the values for lightness $\left(\mathrm{L}^{\star}\right)$ and chroma $\left(\mathrm{a}^{*}\right.$ and $\mathrm{b}^{*}$ ), where we can observe that freezing for 30 days provided increased lightness to the processed potatoes compared to freezing for $24 \mathrm{~h}$, except for the sample blanched with $\mathrm{NaCl}$ 


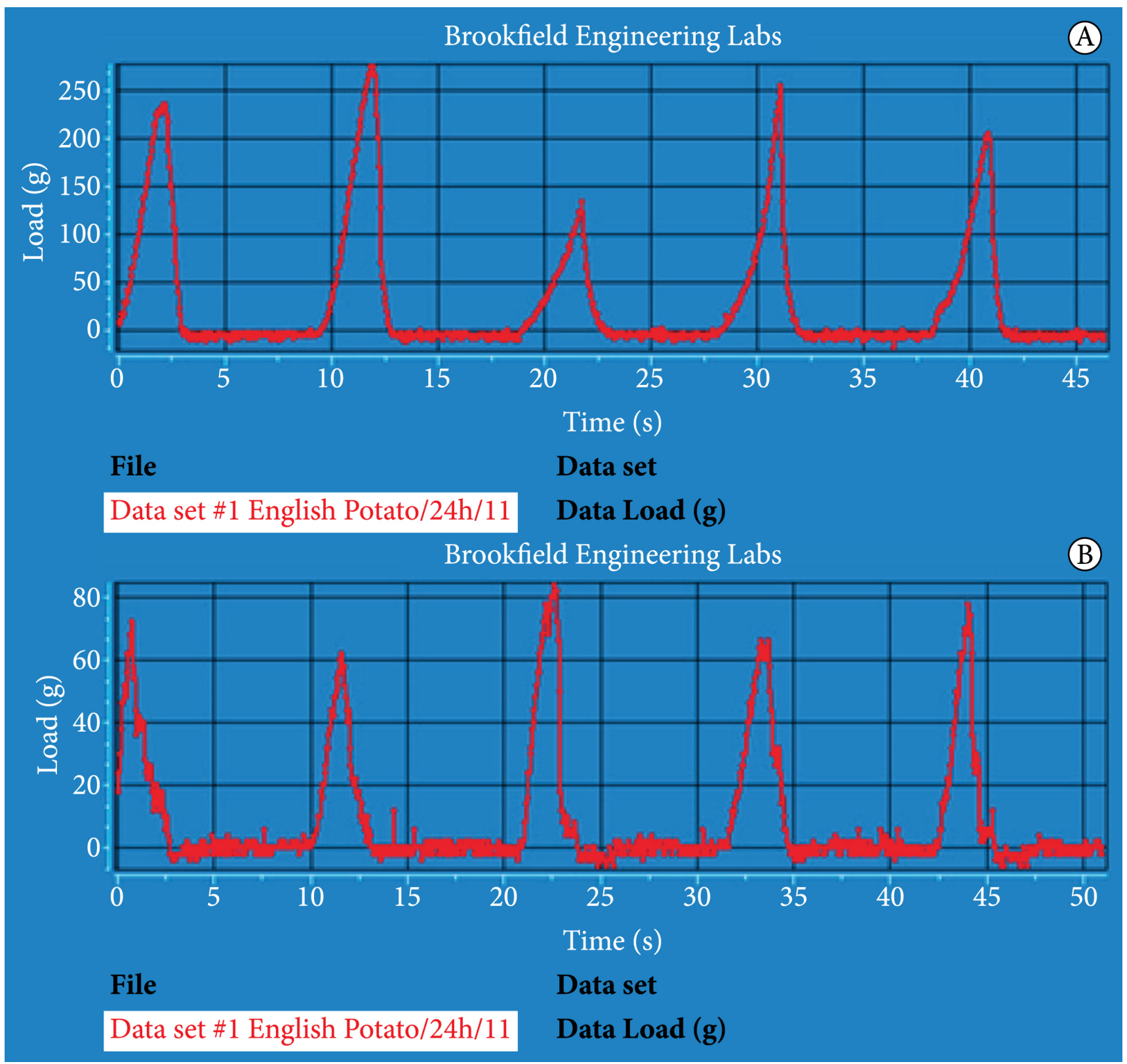

Figure 1. (A) Evaluation of the instrumental texture of fried potatoes subjected to blanching treatment with $\mathrm{B}_{3}\left(\mathrm{NaCl}_{3} \%+\mathrm{CaCl} 3 \%\right)$ frozen for $24 \mathrm{~h}$. (B) Assessment of the instrumental texture of fried potatoes subjected to blanching treatment with $\mathrm{B} 3\left(\mathrm{NaCl}_{3} \%+\mathrm{CaCl}_{2} 3 \%\right)$ frozen for $24 \mathrm{~h}$.

Table 2. Instrumental color of processed potatoes.

\begin{tabular}{crrr}
\hline Sample & $\mathrm{L}^{*}$ & \multicolumn{1}{c}{$\mathrm{a}^{*}$} & $\mathrm{~b}^{*}$ \\
\hline & & Freezing for $24 \mathrm{~h}$ & \\
\hline P & $74.91 \pm 3.38 \mathrm{~B}$ & $-4.52 \pm 1.20 \mathrm{~A}$ & $25.31 \pm 3.95 \mathrm{~A}$ \\
B1 & $73.57 \pm 2.79 \mathrm{~A}$ & $-6.2 \pm 0.87 \mathrm{~A}$ & $25.45 \pm 3.50 \mathrm{~B}$ \\
B2 & $77.58 \pm 1.74 \mathrm{~B}$ & $-5.50 \pm 0.57 \mathrm{~A}$ & $24.94 \pm 2.09 \mathrm{~A}$ \\
B3 & $77.47 \pm 3.97 \mathrm{~B}$ & $-4.78 \pm 0.82 \mathrm{~A}$ & $23.66 \pm 1.68 \mathrm{~A}$ \\
\hline P & Freezing for 30 d & $-4.19 \pm 0.96 \mathrm{~A}$ & $25.34 \pm 4.49 \mathrm{~A}$ \\
B1 & $81.54 \pm 5.26 \mathrm{~A}$ & $-1.79 \pm 1.17 \mathrm{~B}$ & $30.37 \pm 3.27 \mathrm{~A}$ \\
B2 & $76.53 \pm 3.46 \mathrm{~A}$ & $-5.65 \pm 0.57 \mathrm{~A}$ & $21.21 \pm 3.70 \mathrm{~A}$ \\
B3 & $84.84 \pm 3.02 \mathrm{~A}$ & $-6.0 \pm 0.60 \mathrm{~A}$ & $23.06 \pm 1.95 \mathrm{~A}$ \\
\hline
\end{tabular}

Blanching treatments: $\mathrm{P}$ (distilled water); $\mathrm{B} 1(\mathrm{NaCl} 3 \%) ; \mathrm{B} 2\left(\mathrm{CaCl}_{2} 3 \%\right)$; and $\mathrm{B} 3\left(\mathrm{NaCl} 3 \%+\mathrm{CaCl}_{2} 3 \%\right)$. ${ }^{\mathrm{BCC}}$ Equal vertical letters in different freezing times and the same sample do not differ significantly at the $5 \%$ significance level using Student's t-test. 
(B1), which did not differ significantly. This sample was judged sensorially as "slightly better than the standard" showing a significant reduction in green sample $\left(\mathrm{a}^{*}\right)$ from -6.2 to -1.79 , resulting in a more yellow sample $\left(b^{*}\right)$ from 25.45 to 30.37 . These color changes were not observed in the other blanching treatments and freezing times (Table 2). Greater lightness in the samples can be attributed to the blanching effect $(\mathrm{P})$ and the greater potential of the calcium ion (B2 and B3) (Table 2) to reduce non-enzymatic browning through its interaction with asparagine, suppressing the initial stage of the Maillard reaction (Kolek et al., 2006; Gokmen \& Senyuva, 2007).

After frying, the potatoes were sorted on the basis of quality in accordance with $\mathrm{L}^{*}$ parameter values by Coleman (2004): unacceptable $\left(\mathrm{L}^{*}<55\right)$, acceptable $\left(\mathrm{L}^{*} \geq 55\right.$ and $\left.\leq 70\right)$, and high quality $\left(\mathrm{L}^{*}>70\right)$. All the potatoes processed in this study were considered as "high quality" according to this classification.

The blanching treatment that contributed to better flavor was B1, regardless of freezing time (Table 1). This is justified by the fact that sodium is related to the population's eating habits. As for the flavor attribute, blanching treatments using $\mathrm{CaCl}_{2}$ (B2 and B3) were less preferred, because the sensory panel reported that they left a bitter flavor (Table 1). Luna-Guzmán $\&$ Barret (2000) and Batista \& Borges (2013) also found $\mathrm{CaCl}_{2}$ had a potential to leave a bitter flavor in food when using the same salt in minimally processed melon.

For the attribute oiliness, only the potatoes blanched with B1 treatment for 30 days and in treatment with B3 frozen for $24 \mathrm{~h}$ were rated as "slightly better than the standard" (Table 1).
The literature reports that the addition of $\mathrm{CaCl}_{2}$ reduced oil absorption by improving the sensory quality of this attribute (Pedreschi et al., 2007). Moreover, this salt adversely affects the flavor and texture attributes, as shown previously (Figure 1 and Table 1).

The residual oil content (physical-chemical parameter) is an important factor in the nutritional quality of the french fries, and according to data potatoes blanched in treatment with B3 frozen for $24 \mathrm{~h}$ resulted in lower oil levels, reducing $6,14 \mathrm{~g}$ of fat compared to potatoes blanched in treatment with B1 frozen for $24 \mathrm{~h}$, the biggest absorption. This reduced fat absorption is caused by the gelatinization of the starch in the potato surface (Califano \& Calvelo, 1987), which together with the combined action of the salts present in the blanching solution is enhanced by its capacity to stabilize plant tissues against the hot oil (Rimac-Brnčić et al., 2004). The Brazilian food composition table (Universidade Estadual de Campinas, 2011) indicates that fried English potatoes have $13.1 \mathrm{~g}$ of fat, a value close to what was found in this study for the $\mathrm{NaCl}$ treatment (B1) frozen for $24 \mathrm{~h}$, where there was a greater oil absorption.

Because sample B1 obtained the most significant results in the sensory analysis for the attributes such as color, texture, and flavor in the multiple comparison test, and was also the most preferred in the preference ranking test, it was the treatment selected for the study of its microstructural and glycemic aspects, along with the control sample $\mathrm{P}$.

Images from SEM (Figure 2) showed that the microstructural features of the starch granule swelled and lost their original shape, which according to Lee et al. (2011) occurs when the
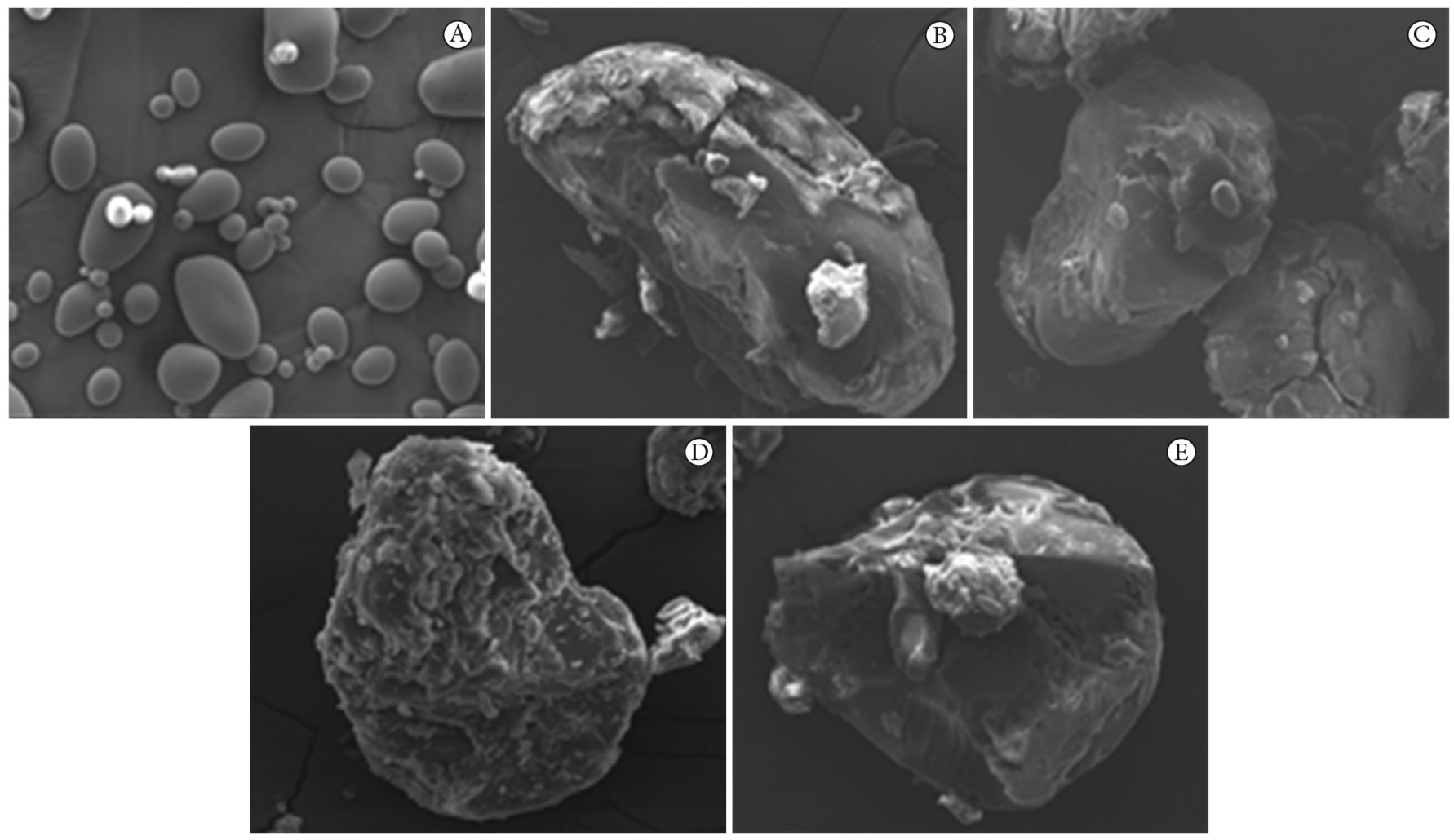

Figure 2. Scanning electron microscopy (SEM) of native potato starches (A), processed: blanching treatment with P frozen for $24 \mathrm{~h}$ (B), B1 frozen for $24 \mathrm{~h}(\mathrm{C}), \mathrm{P}$ frozen for $30 \mathrm{~d}(\mathrm{D})$, and B1 frozen for $30 \mathrm{~d}(\mathrm{E})$. 
granules undergo hydrothermal treatments. Native potato starch is characterized by circular and oval granules ranging from $15 \mu \mathrm{m}$ to $45 \mu \mathrm{m}$ in size (Figure 2A) (McPherson \& Jane, 1999; Leonel, 2007). The size of the granules varied according to blanching and freezing time: $555 \mu \mathrm{m}$ (Figure 2B), $294 \mu \mathrm{m}$ (Figure 2C), $203.5 \mu \mathrm{m}$ (Figure 2D), and $202.5 \mu \mathrm{m}$ (Figure 2E). After 30 days of freezing, both were reduced in size probably due to the rearrangement of the amylose and amylopectin molecules that cause contraction in the granule and syneresis. Research shows that the use of $\mathrm{NaCl}$ has an inhibitory effect on the gelatinization of the starch granule (Bello-Perez \& ParedesLopez, 1995). This effect was observed in this study when comparing the sizes of granules from the $\mathrm{P}$ and $\mathrm{B} 1$ samples frozen for $24 \mathrm{~h}$ (Figure $2 \mathrm{~B}$ and $2 \mathrm{C}$ ).

As for the shape and surface of the granules, cracks, dents, smaller aggregated starch granules, and fragments were observed on the surface of the granules due to gelatinization, the use of high temperatures, and rupture caused by the abundance of water molecules present in the blanching treatments (Lee et al., 2012). Bouchon \& Aguilera (2001) reported that the structural modifications of the starch granules from gelatinized potatoes occur at temperatures above $72{ }^{\circ} \mathrm{C}$, causing them to deform without disrupting the cellular structure.
The difference between the types of crystallinity of the granules is in the packaging of the amylose and amylopectin chains, and the water content of the sample is changed with the reorientation of the crystal due to blanching (Gunaratne \& Hoover, 2002).

The diffraction peaks are used to identify the crystalline form of the food under study (Singh et al., 2006). It was observed that native potato starch granules (Figure $3 \mathrm{~A}$ ) showed crystallinity pattern type $B$ characterized by intensity peaks at $6.3 ; 17 ; 19.3$; and between $22^{\circ}$ and $24^{\circ}$ in $2 \theta$ angle (McPherson \& Jane, 1999), and decreased susceptibility to enzyme attack (Jane et al., 1997). The diffractograms for the samples isolated from potato starch (Figures 3B, 3C, 3D, and 3E) showed small changes resulting from the application of blanching and freezing treatments used in this study.

In Figures $3 \mathrm{~B}$ and $3 \mathrm{C}$, it was noted that freezing for $24 \mathrm{~h}$ showed smaller peaks, but for the 30 days period, the definition of the peaks increased in both blanching treatments (Figures 3D and 3E), although this did not modify the crystallinity of the granule pattern. This result is due to the retrogradation of the amylopectin chains, which occurs more slowly because it involves the association of their branches, which are capable of reducing the percentage of amorphous area (Morrison et al., 1993). For blanching treatment

\section{Commander Sample ID (Coupled Two Theta/Theta)}

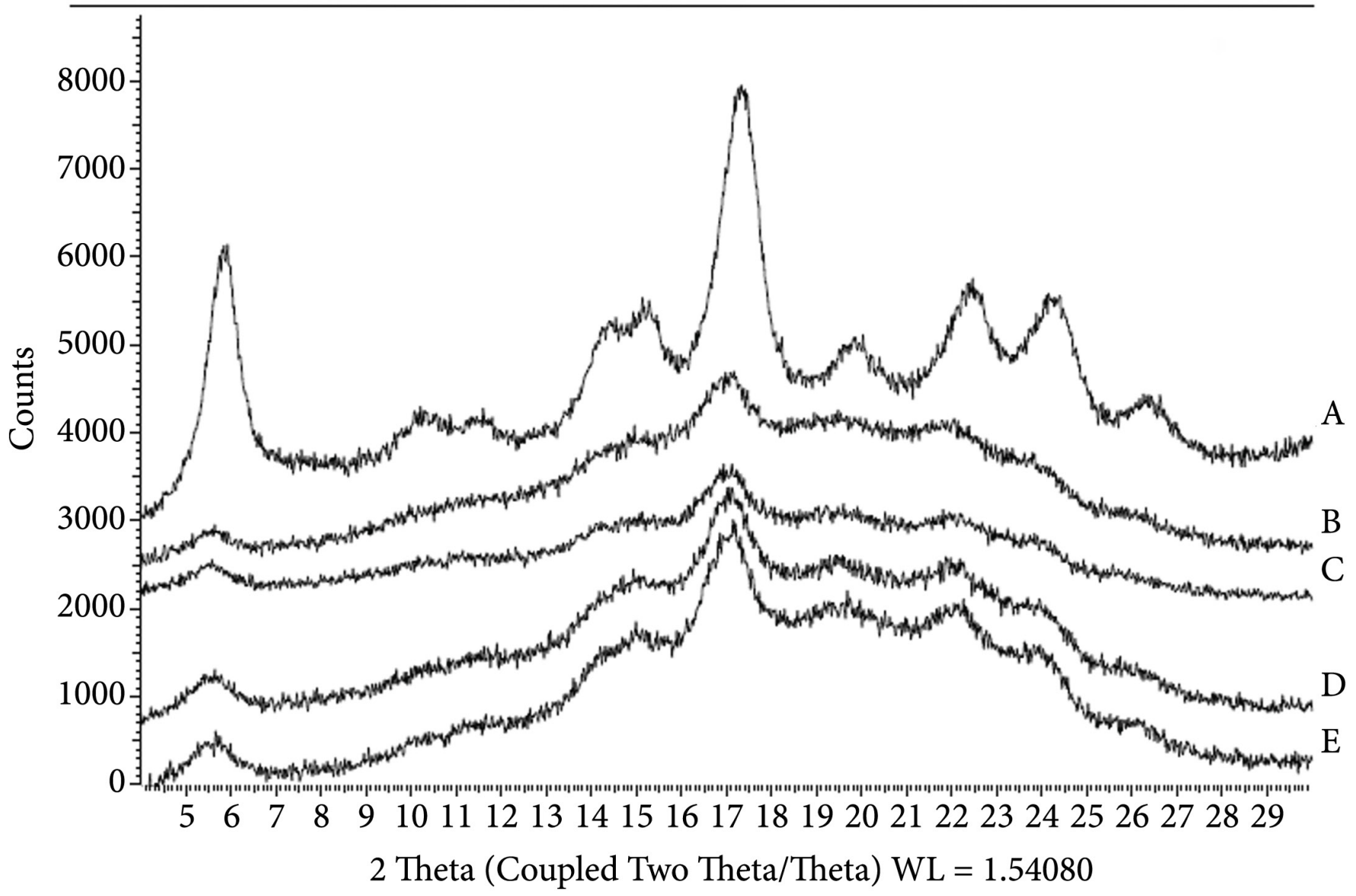

Figure 3. X-ray diffraction of the processed potato starches: (A) native potato starch; (B) blanching treatment with P frozen for 24 h; (C) B1 frozen for $24 \mathrm{~h}$; (D) P frozen for $30 \mathrm{~d}$; and (E) B1 frozen for $30 \mathrm{~d}$. 
Table 3. Carbohydrate fractions (g/100 g), glycemic index, glycemic load crystalline and amorphous area of processed potatoes.

\begin{tabular}{ccccc}
\hline Sample & RS & DF & GI & GL \\
\hline P 24 h & $3.76 \pm 0.05 \mathrm{a}$ & $3.50 \pm 0.03 \mathrm{~d}$ & $55.43 \pm 0.05 \mathrm{a}$ & $10.40 \pm 0.04 \mathrm{c}$ \\
B1 24 h & $2.85 \pm 0.02 \mathrm{~b}$ & $5.08 \pm 0.02 \mathrm{~b}$ & $53.86 \pm 0.80 \mathrm{~b}$ & $13.94 \pm 0.04 \mathrm{a}$ \\
P 30 d & $2.69 \pm 0.05 \mathrm{c}$ & $4.90 \pm 0.03 \mathrm{c}$ & $52.12 \pm 0.12 \mathrm{c}$ & $12.00 \pm 0.03 \mathrm{~b}$ \\
B1 30 d & $2.31 \pm 0.02 \mathrm{~d}$ & $6.03 \pm 0.03 \mathrm{a}$ & $50.42 \pm 0.12 \mathrm{c}$ & $10.30 \pm 0.07 \mathrm{c}$ \\
\hline
\end{tabular}

Blanching treatments: $\mathrm{P}$ (distilled water) frozen for $24 \mathrm{~h} ; \mathrm{B} 1(\mathrm{NaCl} 3 \%$ solution) frozen for $24 \mathrm{~h}$; P30 frozen for $30 \mathrm{~d}$, and B1 frozen for $30 \mathrm{~d}$. The same vertical letters do not differ significantly at the $5 \%$ significance level by the Duncan test. RS: Resistant starch; DF: Dietary fiber; GI: Glycemic Index; GL: Glycemic Load.

with B1 frozen for 30 days (Figure 3D), the longer frozen storage time favored the more intense recrystallization of the granules.

The carbohydrate fractions, glycemic index, and glycemic load of the processed potatoes are presented in Table 3 . Although the literature reports that frozen storage source of starchy foods promotes the formation of resistant starch (Rosin et al., 2002), the content of this constituent decreased in the processed potatoes (from $3.76 \mathrm{~g}$ to $2.31 \mathrm{~g}$ ) as the freezing time increased (Table 3 ). The findings were possibly affected by the lowered amylose content in the potato ( $20 \%$ to $37 \%$ ), because a higher percentage of amylose leads to increased formation of resistant starch (Escarpa et al., 1996; Müller et al., 2009).

It has also been suggested that because it is a fried food, there were interactions between the starch and the oils forming complexes that resulted in lower amylose availability to form indigestible fractions (Szczodrak \& Pomeranz, 1992). Other authors have reported that intermolecular bonds of varying strength exist in resistant starch, modifying the levels in foods according to temperature, humidity, heating/cooling cycles, presence of oils, size of amylose and amylopectin chains, and storage temperature/time (Szczodrak \& Pomeranz, 1992; Sievert \& Pomeranz, 1989; Ai et al., 2013).

The values for dietary fiber shown in Table 3 are within the range described in the literature (Mendez et al., 1995; Lajolo \& Menezes, 2006; Universidade Estadual de Campinas, 2011). The use of the enzymatic gravimetric method (AOAC 991.43) to measure dietary fiber determines part of the resistant starch, and therefore the increase in fiber during freezing may possibly be due to small fractions of resistant starch measured by the enzymatic gravimetric method (Association of Official Analytical Chemists, 2002).

Among the treatments studied, blanching treatment with $\mathrm{P}$ frozen for $24 \mathrm{~h}$ had the highest glycemic response along with the highest resistant starch content $(3.76 \mathrm{~g}$ ) and lowest dietary fiber content $(3.50 \mathrm{~g}$ ) (Table 3). Helbig et al. (2008) found that different levels of resistant starch in samples of processed rice did not result in the reduction of glycemic response. Caruso \& Menezes (2000) demonstrated a higher glycemic response in corn flakes with higher levels of resistant starch and quickly digestible starch, thus demonstrating that there is not yet a consensus regarding the influence of elevated resistant starch content and reduced glycemic response.
All samples studied were considered to have a low GI (Table 3), classified by Lajolo \& Menezes (2006) as follows: low $(\leq 55)$, moderate (56-79), and high ( $\geq 70)$. The literature reports GI values for french fries ranging from 70 to 107 (Food and Agriculture Organization, 1998; Foster-Powell et al., 2002; Sidney University Glycemic Index Research Service, 2011). However, lower values were found in this study (Table 3 ), emphasizing the influence and importance of processing on the bioavailability of potato starch, as reported by Lee \& Moon (2015).

Glycemic load is another predictor of glycemic response, considering that the available portion of carbohydrates together with glycemic index enables a better understanding of starch bioavailability. Foods are classified as follows: low GL $(\leq 10)$, comprising slowly digested carbohydrates; moderate CG (11-19); and high CG $(\geq 20)$, comprising quickly digested carbohydrates (Brand-Miller et al., 2003; Sidney University Glycemic Index Research Service, 2011). The potatoes processed in this study had moderate glycemic loads (Table 3 ), an effect attributed to the ready availability of carbohydrates in digestion, but these data contrast with the values reported in the literature, which estimates high glucose loads for this food (Foster-Powell et al., 2002).

\section{Conclusion}

Potatoes blanched in sodium chloride solution presented better sensory quality for the attributes such as color, texture, flavor, and greater overall preference. A mixture of sodium chloride and calcium chloride in the blanching solution, despite providing less oil absorption and less oiliness, yielded a more rigid texture and lower overall preference.

A 30-day freezing period increased the lightness of the french fries, except when sodium chloride was used, which intensified the yellow color.

Blanching treatments with $\mathrm{NaCl}$ did not alter the crystal type of the starch; however, longer freezing time increased the percentage of crystalline area, reduced the content of resistant starch, and reduced the glycemic index and concentrated dietary fiber content, so that all the processed potatoes exhibited low glycemic indices and moderate glycemic loads.

\section{References}

Ai, Y., Hasjim, J., \& Jane, J. L. (2013). Effects of lipids on enzymatic hydrolysis and physical properties of starch. Carbohydrate Polymers, 92(1), 120-127. http://dx.doi.org/10.1016/j.carbpol.2012.08.092. PMid:23218274.

Associação Brasileira de Normas Técnicas - ABNT. (1995). NBR 13526: Teste de comparação múltipla em análise sensorial dos alimentos e bebidas. Rio de Janeiro.

Association of Official Analytical Chemists - AOAC. (2002). Official methods of Analysis of AOAC (18th ed). Gaithersburg: AOAC International.

Batista, A. P., \& Borges, C. D. (2013). Métodos de conservação aplicados a melão minimamente processado. Ciência Rural, 43(5), 915-923. http://dx.doi.org/10.1590/S0103-84782013005000046.

Bello-Perez, L. A., \& Paredes-Lopez, O. (1995). Starch and amylopectin: Effects of solutes in their calorimetric behavior. Carbohydrate Polymers, 38, 243-247. 
Bouchon, P., \& Aguilera, J. M. (2001). Microestructural analysis of frying potatoes. International Journal of Food Science and Technology, 36(6), 669-676.

Brand-Miller, J., Hayne, S., Petocz, P., \& Colagiuri, S. (2003). Lowglycemic index diets in the management of diabetes: a meta-analysis of randomized controlled trials. Diabetes Care, 26(8), 2261-2267. http://dx.doi.org/10.2337/diacare.26.8.2261. PMid:12882846.

Brasil, Ministério da Saúde, Agência Nacional de Vigilância Sanitária. (2001). Regulamento técnico sobre os padrões microbiológicos para alimentos (Resolução RDC no 12 de 02 de janeiro de 2001). Diário Oficial [da] República Federativa do Brasil.

Bunger, A., Moyano, P., \& Rioseco, V. (2003). Nacl soaking treatment for improving the quality of french-fried potatoes. Food Research International, 36(2), 161-166. http://dx.doi.org/10.1016/S09639969(02)00131-X.

Califano, A. N., \& Calvelo, A. (1987). Adjustment of surface concentration of reducing sugars before frying of potato strips. Journal of Food Processing and Preservation, 12(1), 1-9. http://dx.doi. org/10.1111/j.1745-4549.1988.tb00062.x.

Caruso, L., \& Menezes, E. W. (2000). Índice glicêmico dos alimentos. Nutrire, 19(20), 49-63.

Coleman, W. K. (2004). Comparative performance of the $\mathrm{L}^{\star} \mathrm{a}^{*} \mathrm{~b}^{*}$ color space and North American color charts for determining chipping quality in tubers of potato (Solanum tuberosum L.). Canadian Journal of Plant Science, 84(1), 291-298. http://dx.doi.org/10.4141/P02-164.

Escarpa, A., González, M. C., Mañas, E., Garcia-Diz, L., \& SauraCalixto, F. (1996). Resistant starch formation: standardization of a high-pressure autoclave process. Journal of Agricultural and Food Chemistry, 44(3), 924-928. http://dx.doi.org/10.1021/jf950328p.

Food and Agriculture Organization - FAO. World Health Organization - WHO. (1998). Carbohydrates in human nutrition: report of a joint FAO/WHO expert consultation (Food and Nutrition Paper). Rome.

Foster-Powell, K., Holt, S. H. A., \& Brand-Miller, J. C. (2002). International table of glycemic index and glycemic load values: 2002. The American Journal of Clinical Nutrition, 76(1), 5-56. PMid:12081815.

Gokmen, V., \& Senyuva, H. Z. (2007). Acrylamide formation is prevented by divalent cations during the Maillard reaction. Food Chemistry, 103(1), 196-203. http://dx.doi.org/10.1016/j.foodchem.2006.08.011.

Goñi, I., Garcia Alonso, A., \& Saura-Calixto, F. (2002). A starch hydrolysis procedure to estimate glycemic index. Nutrition Research, 17(3), 427-437. http://dx.doi.org/10.1016/S0271-5317(97)00010-9.

Goñi, I., Menezes, E. W., Dan, M. C., Cardenette, G. H., Bello-Pérez, L. A., \& Lajolo, F. M. (2010). In vitro colonic fermentation and glycemic response of different kinds of unripe banana flour. Plant Foods for Human Nutrition (Dordrecht, Netherlands), 65(4), 379-385. http:// dx.doi.org/10.1007/s11130-010-0190-4. PMid:20839056.

Gunaratne, A., \& Hoover, R. (2002). Effect of heat-moisture treatment on the structure and physicochemical properties of tuber and root starches. Carbohydrate Polymers, 49(4), 425-437. http://dx.doi. org/10.1016/S0144-8617(01)00354-X.

Helbig, E., Días, A. R. G., Tavares, R. A., Schirmer, M. A., \& Elias, M. C. (2008). Arroz parboilizado efeito na glicemia de ratos Wistar. Archivos Latinoamericanos de Nutricion, 58(2), 149-155. PMid:18833992.

International Comission on Ilumination - CIE. (2004). Technical report: colorimetry (3rd ed.). Austria.

International Standard Organization - ISO. (2006). ISO 8587:2006: describes a method for sensory evaluation with the aim of placing a series of test samples in rank order.

Jane, J. L., Wong, K. S., \& McPherson, A. E. (1997). Branch -structure difference in starches of A- and B- type X-ray patterns revealed by their Naegelidextrins. Carbohydrate Research, 300(3), 219-227. http://dx.doi.org/10.1016/S0008-6215(97)00056-6.

Kolek, E., Šimko, P., \& Simon, P. (2006). Inhibition of acrylamide formation in asparagine/D-glucose model system by nacl addition. Journal European Food Research and Technology, 224(2), 283-284. http://dx.doi.org/10.1007/s00217-006-0319-8.

Lajolo, F. M., \& Menezes, E. W. (2006). Carbohidratos en alimentos regionales iberoamericanos. São Paulo: Editora da Universidade de São Paulo.

Lee, C. J., \& Moon, T. W. (2015). Structural characteristics of slowly digestible starch and resistant starch isolated from heat-moisture treated waxy potato starch. Carbohydrate Polymers, 125, 200-205. http://dx.doi.org/10.1016/j.carbpol.2015.02.035. PMid:25857975.

Lee, C. J., Kim, Y., Choi, S. J., \& Moon, T. W. (2012). Slowly digestible starch heat-moisture treated waxy potato starch: Preparation, structural, and glucose response in mice. Food Chemistry, 133(4), 1222-1229. http://dx.doi.org/10.1016/j.foodchem.2011.09.098.

Lee, C. J., Shin, S. I., Kim, Y., Choi, S. J., \& Moon, T. W. (2011). Structural characteristics and glucose response in mice of potato starch modified by hydrothermal treatments. Carbohydrate Polymers, 83(4), 18791886. http://dx.doi.org/10.1016/j.carbpol.2010.10.057.

Leonel, M. (2007). Análise da forma e tamanho de grânulos de amidos de diferentes fontes botânicas. Ciência e Tecnologia de Alimmentos, 27(3), 579-588. http://dx.doi.org/10.1590/S0101-20612007000300024.

Luna-Guzmán, I., \& Barret, D. M. (2000). Comparison of calcium chloride and calcium lactate effectiveness in maintaining shelf stability and quality of fresh cut cantaloupes. Postharvest Biology and Technology, 19(1), 61-72. http://dx.doi.org/10.1016/S0925-5214(00)00079-X.

McPherson, A. E., \& Jane, J. (1999). Comparison of waxy potato with other root and tuber staches. Carbohydrate Polymers, 40(1), 57-70. http://dx.doi.org/10.1016/S0144-8617(99)00039-9.

Mendez, M. H. M., Derivi, S. C. N., Rodrigues, M. C. R., \& Fernandes, M. L. (1995). Tabela de composição de alimentos: amiláceos, cereaise derivados, frutas, hortaliças, leguminosas, nozes, e oleaginosas. Niterói: Editora da Universidade Federal Fluminense. 41 p.

Morrison, W. R., Tester, R. F., Snape, C. E., Law, R., \& Gidley, M. J. (1993). Swelling and gelatinization of cereal starch. IV: some effects of lipid-complexed amylose and free amylose in waxy and normal barley starches. Cereal Chemistry, 70, 385-391.

Müller, D. R., Bisognin, D. A., Andriolo, J. L., Morin, G. R. Jr., \& Gnocato, F. S. (2009). Expressão dos caracteres e seleção de clones de batata nas condições de cultivo de primavera e outono. Ciência Rural, 39(5), 1327-1334. http://dx.doi.org/10.1590/S0103-84782009005000078.

Oner, M. E., \& Walker, P. N. (2011). Shelf life of near-asseptically packaged refrigerated potato strips. LWT - Food Science and Technology, 44, 1616-1620.

Pardo, J. E., Alvarruiz, A., Perez, J. I., Gomez, R., \& Varón, T. (2000). Physical-chemical and sensory quality evaluation of potato varieties (solanum tuberosum L.). Journal of Food Quality, 23(2), 149-160. http://dx.doi.org/10.1111/j.1745-4557.2000.tb00202.x.

Pedreschi, F., Granby, K., \& Risum, J. (2009). Acrylamide mitigation in potato chips by using $\mathrm{NaCl}$. Food and Bioprocess Technology, 3(6), 917-921. http://dx.doi.org/10.1007/s11947-010-0349-x.

Pedreschi, F., Kaack, K., Granby, K., \& Troncoso, E. (2007). Acrylamide reduction under different pre-treatments in French fries. Journal of Food Processing Engeneering, 79(4), 1287-1294. http://dx.doi. org/10.1016/j.jfoodeng.2006.04.014.

Pereira, S. E. M., Luz, J. N. Q., \& Moura, C. C. (2005). A batata e seus benefícios nutricionais. São Paulo: Edufu. 
Rimac-Brnčić, S., Lelas, V., Rade, D., \& Simundic, B. (2004). Decreasing of oil absorption in potato strips during deep fat frying. Journal of Food Engineering, 64(2), 237-241. http://dx.doi.org/10.1016/j. jfoodeng.2003.10.006.

Rocha, T. S., Demiate, I. M., \& Franco, C. M. L. (2008). Características estruturais e físico-químicas de amidos de mandioquinha-salsa (Arracaciaxanthorrhiza). Ciência e Tecnologia de Alimentos, 28(3), 620-628. http://dx.doi.org/10.1590/S0101-20612008000300018.

Rosin, P. M., Lajolo, M. F., \& Menezes, E. W. (2002). Measurement and characterization of dietary starches. Journal of Food Composition and Analysis, 15(4), 367-377. http://dx.doi.org/10.1006/jfca.2002.1084.

Salmerón, J., Manson, J. E., Stampfer, M. J., Colditz, G. A., Wing, A. L., \& Willett, W. C. (1997). Dietary fiber, glycemic load, and risk of non-insulin-dependent diabetes mellitus in women. The Journal of American Medical Association, 277(6), 472-477.

Sanibal, E. A. A., \& Mancini, J. Fo. (2004). Perfil de ácidos graxos trans de óleo e gordura hidrogenada de soja no processo de fritura. Ciência e Tecnologia de Alimentos, 24(1), 27-31. http://dx.doi.org/10.1590/ S0101-20612004000100006.

Sidney University Glycemic Index Research Service - SUGIRS. (2011). Glycemic index. Retrieved from http://www.glycemicindex.com/ foodsearch.php
Sievert, D., \& Pomeranz, Y. (1989). Enzyme resistant starch. I. Characterization and evaluation by enzymatic, thermoanalytical, and microscopic methods. Cereal Chemistry, 66, 342-347.

Singh, J., Dartois, A., \& Kaur, L. (2006). Starch digestibility in a food matrix: a review. Trends in Food Science \& Technology, 21(4), 168180. http://dx.doi.org/10.1016/j.tifs.2009.12.001.

Szczodrak, J., \& Pomeranz, Y. (1992). Starch-lipid interactions and formation of resistant starch in high-amylose barley. Cereal Chemistry, 69(6), 626-632.

Troncoso, E., Pedreschi, F., \& Zuniga, R. N. (2009). Comparative study of physical and sensory properties of pre-treated potato slices during vacuum and atmospheric frying. LWT - Food Science and Technology, 42, 187-195.

Universidade Estadual de Campinas - UNICAMP. Núcleo de estudos e pesquisas em alimentação - NEPA. (2011). Tabela Brasileira de Composição de Alimentos: TACO (4th ed.). Campinas. Retrieved from http://www.unicamp.br/nepa/taco/

Vendruscolo, J. L. S., \& Zorzella, C. A. (2002). Processamento de batata (Solanum tuberosum L.): fritura. Pelotas: Embrapa Clima Temperado.

Zvitov-Yaari, R., \& Nussinovitch, A. (2014). Browning prevention in rehydratred freeze-dried non-blanched potato slices by electrical treatment. LWT - Food Science and Technology, 56, 194-199. 